\title{
Comparison of the Impact of Long-Term Applications of MTAD and EDTA Irrigation Agents on Dentin Structure: A Scanning Electron Microscope Study
}

\author{
Sadullah Kaya ${ }^{1}$, Selengül Ganidağlı Ayaz ${ }^{2}$, İbrahim Uysal ${ }^{2}$, Zeki Akkuş ${ }^{3}$ \\ ${ }^{1}$ Assistant Professor, Dicle University, Faculty of Dentistry, Department of Endodontics, Diyarbakır, TURKEY \\ 2 Research Assistant, Dicle University, Faculty of Dentistry, Department of Endodontics, Diyarbakır, TURKEY \\ ${ }^{3}$ Associate Professor, Dicle University, Faculty of Medicine, Department of Biostatistics, Diyarbakır, TURKEY
}

\section{Key Words}

MTAD, EDTA, demineralization

\section{Correspondence:}

Sadullah KAYA

Dicle University,

Faculty of Dentistry,

Department of Endodontics,

21280, Diyarbakir, TURKEY.

e-mail: sadullahkaya@hotmail.com

\begin{abstract}
Aim: The purpose of this study was to compare the effects of 20min applications of MTAD and 15\% ethylenediaminetetraacetic acid (EDTA) solutions during final irrigation on the demineralization of root canal dentin.
\end{abstract}

Methodology: Forty mandibular and maxillary single-rooted teeth were randomly divided into two groups. During initial irrigation following the use of each file, $2 \mathrm{~mL}$ of $2.5 \%$ sodium hypochloride $(\mathrm{NaOCl})$ solution was applied to all teeth. During final irrigation, $5 \mathrm{~mL}$ of EDTA solution was applied to the teeth in Group 1 and $5 \mathrm{~mL}$ MTAD solution was applied to the teeth in Group 2. Both solutions were applied for $20 \mathrm{~min}$. All teeth were then washed with $5 \mathrm{~mL}$ distilled water and dried with paper points. The teeth were buccolingually bisected along the long axes using hammers and chisels. Scanning electron microscopic (SEM) images were then obtained and scored.

Results: Mann-Whitney $U$ tests revealed significant differences between the MTAD and EDTA groups $(p<0.001)$.

Conclusions: The EDTA solution produced more demineralized areas in the dentin tubules than the MTAD solution.

(Int Dent Res 2011;2:60-64)

\section{Introduction}

A successful endodontic treatment requires good shaping, removal of infected tissues, and through filling of the canal. Use of appropriate irrigation agents and instruments are key to success. Smear layers produced by rotary and hand instrumentation of the root canal contain remnant bacteria, pulpal debris, and toxins. A smear layer on the canal wall weakens adhesion between canal sealers used in endodontic treatment and the dentin wall. Removal of the smear layer facilitates proper adhesion and prevents the occurrence of postoperative problems (1-5).
Sodium hypochlorite $(\mathrm{NaOCl})$ solution, an antibacterial tissue solvent, is the most widely used irrigation agent. Although $\mathrm{NaOCl}$ effectively removes organic residues, it is ineffective in removing inorganic residues. It should be used in combination with chelating agents to for total debridment(6-8).

Several chelating agents have been recommended for the removal of the smear layer, including BioPure MTAD (Dentsply/Tulsa, Tulsa, OK, USA), ethylenediaminetetraacetic acid, citric acid, EDTAC, REDTA, Glyde files, apple cider vinegar, and RC-Prep (8-14). EDTA effectively removes the smear layer and is one of the most preferred chelating agents in endodontics. The application of 
$10 \mathrm{~mL}$ of $5.25 \% \mathrm{NaOCl}$ following $10 \mathrm{~mL}$ of $17 \%$ EDTA effectively removes the organic and inorganic components of the smear layer $(6,15)$. A proper chelating agent must not cause structural changes to the dentin surface during smear layer removal. The effectiveness of a chelating agent depends on a number of factors, including dentin hardness, penetration strength of the solution, root canal length, application period, $\mathrm{pH}$, and concentration of the material (15).

Çalt and Serper (16) reported that a 10-min application of $17 \%$ EDTA as an irrigation agent caused peri- and intratubular dentinal erosion. Cury et al. (17) found the effects of EDTA solution on dentin demineralization to be pH-dependent, with the greatest demineralization caused by $0.3 \mathrm{M}$ EDTA solution with a pH of 5-6. Commercial EDTA preparations have a $\mathrm{pH}$ of 7.3. Lower $\mathrm{pH}$ values may create higher solubility of hydroxyapatite, causing demineralization (18).

Torabinejad et al. (8) developed BioPure MTAD, an antibacterial agent containing tetracycline isomer, citric acid, and detergent that effectively cleans and disinfects root dentin (8). MTAD is a biocompatible material with a solvent effect on dentin and pulp that is similar to that of EDTA, without containing doxycycline. MTAD has a wide range of antibacterial effectiveness and binds to dentin, differentiating this agent from EDTA (8,19-21). Moreover, the microstructural dentin changes induced by BioPure MTAD do not appear to cause significant damage when the agent is used as a final rinse in conjunction with low concentrations of $\mathrm{NaOCl}$ (22). Unlike EDTA and citric acid, the combined use of BioPure MTAD and $\mathrm{NaOCl}$ is reported to create minimal erosion of the intraradicular dentin surfaces (19).

The purpose of the present study was to evaluate the presence of dentinal erosion in the coronal, middle, and apical thirds of root canals by the application of $15 \%$ EDTA and MTAD solutions during final irrigation under scanning electron microscopic.

\section{Materials and Methods}

In this study, 40 intact maxillary and mandibular single-rooted teeth were used that had been extracted during periodontal or prosthetic treatment. The teeth were stored in $0.1 \%$ thymol solution at $4{ }^{\circ} \mathrm{C}$ until use. The crowns were removed at the dentin-enamel junction with a diamond disk (KG Sorensen, Barueri, SP, Brazil) under water cooling. Working lengths were defined $1 \mathrm{~mm}$ short of the apices with size-10 and -15 K-files. Each canal was instrumented using a combination of the passive step-back technique to size F3 using ProTaper (Dentsply Maillefer, Ballaigues,
Switzerland). Irrigation ( $2 \mathrm{~mL}$ of $2.5 \% \mathrm{NaOCl}$ ) was performed using a 27-gauge needle after each instrument. The teeth were then randomly divided into two groups for the final irrigation regime, and received a 20 -min application of 15\% EDTA (EDTA; Roth International Ltd., Chicago, IL, USA) solution (Group 1; $5 \mathrm{~mL}$ ) or MTAD solution (Group 2; $5 \mathrm{~mL}$ ). All teeth were then washed with $5 \mathrm{~mL}$ distilled water and dried with paper points.

\section{SEM Evaluation}

Two longitudinal grooves were prepared on the buccal and lingual surfaces of each root using a diamond disc, avoiding penetration into the canal. The roots were then split into 2 halves with a chisel and coded. The coded specimens were mounted on metallic stubs, gold sputtered, and examined independently by two observers using scanning electron microscopic (SEM; JEOL T330; JSM, Tokyo, Japan) after the examination of 20 specimens for calibration purposes. The proximate center of each third was also photographed at a higher magnification of 5000x for evaluation of dentinal erosion. Erosion levels in dentinal tubules were determined using the scoring system developed by Torabinejad et al. (8): score $1=$ no erosion (all tubules look normal in appearance and size), score 2 $=$ moderate erosion (peritubular dentin is eroded), and score 3 = severe erosion (intertubular dentin is destroyed, and tubules are connected to one another). Intra- and interexaminer reliability for the SEM assessment was verified by the Kappa test. The groups were compared statistically using the MannWhitney U test.

\section{Results}

The coronal, middle, and apical thirds of the root canals in the EDTA group showed areas of periand intratubular dentinal resorption, whereas no significant resorption was detected in the canals of the MTAD group. Multiple comparisons found significant differences between groups $(p<0.001$; Table 1; Fig. 1).

TABLE 1. Mean dentinal erosion scores for each region. $(p<0.001)$

\begin{tabular}{|ccc|}
\hline Regions & $\begin{array}{r}\text { NaOCl/EDTA } \\
\text { Mean } \pm \text { SD }\end{array}$ & $\begin{array}{r}\text { NaOCl / MTAD } \\
\text { Mean } \pm \text { SD }\end{array}$ \\
\hline Coronal & $2.35 \pm 0.49^{\mathrm{a}}$ & $1.25 \pm 0.44^{\mathrm{c}}$ \\
Middle & $2.35 \pm 0.49^{\mathrm{a}}$ & $1.25 \pm 0.44^{\mathrm{c}}$ \\
Apical & $2.40 \pm 0.50^{\mathrm{b}}$ & $1.50 \pm 0.69^{\mathrm{d}}$ \\
\hline
\end{tabular}

SD: standard deviation. 


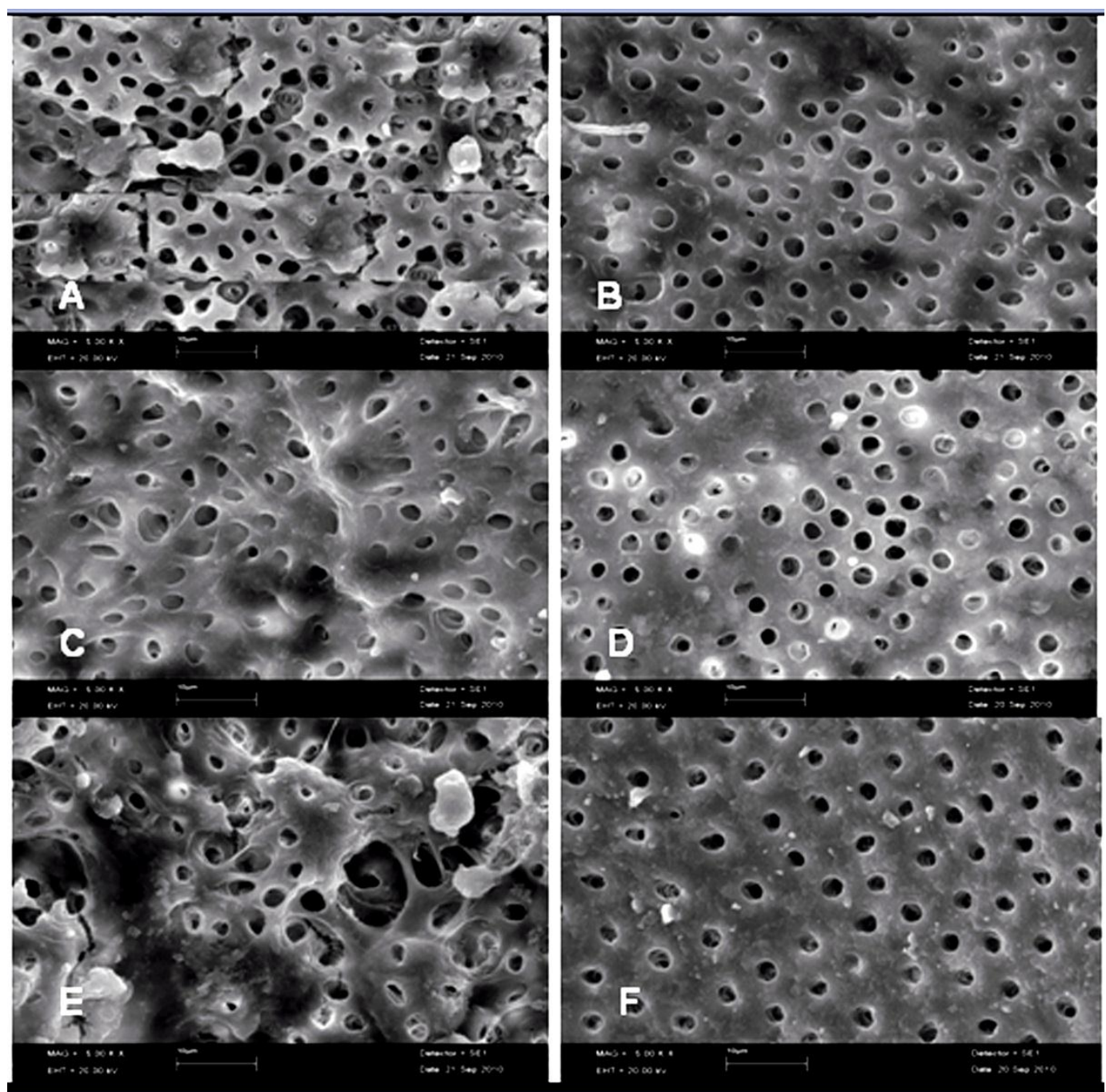

Figure 1. Scanning electron microscopic images of root canal walls (5000x). (A) Group 1, EDTA treatment, coronal third (erosion score 3); (B) Group 2, MTAD treatment, coronal third (erosion score 1); (C) Group 1, EDTA treatment, middle third (erosion score 3); (D) Group 2, MTAD treatment, middle third (erosion score 2), (E) Group 1, EDTA treatment, apical third (erosion score 3), (F) Group 2, MTAD treatment, apical third (erosion score 2).

\section{Discussion}

The purpose of this study was to compare the demineralization in dentin tubules caused by $20-$ min applications of MTAD and 15\% EDTA solutions during the final irrigation of root canals.

Berutti et al. (23) stated that solutions used as irrigation agents could penetrate about $130 \mu \mathrm{m}$ into the internal surfaces of root dentin. However, bacteria may be present in root dentinal tubules at $400-500-\mu \mathrm{m}$ depths in cases of serious bacterial invasion (24). To achieve proper antibacterial effectiveness, irrigation agents should remove organic and inorganic tissues in root canals, open dentinal tubules, and penetrate into the root canal system. The effectiveness of an irrigation agent is thus typically evaluated by comparing its application for different time intervals $(1-10 \mathrm{~min})(8,25)$. During removal of the smear layer and debris residues, chelating agents can cause erosion of the dentin walls. In this study, Our used 20 min applications of the two chelating agents to allow observation of long-term peri- and intratubular changes in the dentin canal openings.

$\mathrm{NaOCl}$ and EDTA are widely used irrigation agents in endodontics. However, long-term use of these agents at high concentrations can cause undesired effects on the root canal walls, such as significantly reduced flexural strength, microhardness, root canal dentin roughness, and elastic modulus (26-28). Çalt and Serper (16) reported that a 10 -min application of $17 \%$ EDTA as an irrigation agent caused peri- and intratubular dentinal erosion. The present study corroborated these findings.

Several recent studies (22) have found that the combined use of high concentrations of EDTA and 
$\mathrm{NaOCl}$ effectively removed smear layers, however caused dentinal erosion. Baumgartner and Mader (7) reported that the combined use of EDTA and $\mathrm{NaOCl}$ caused widespread degradation in the peri- and intratubular dentinal zones, creating 2.5-4- $\mu \mathrm{m}$ areas of erosion. This impact, verified by several EDTA studies $(16,19,29)$, can impede the adaptation of canal filling materials to dentin walls. Erosion of root canal dentin and dentinal tubules can depend on many factors, such as the type, amount, concentration, $\mathrm{pH}$, and application time of the irrigation agent. Niu et al. (29) reported that the use of $6 \% \mathrm{NaOCl}$ for final irrigation following $3 \mathrm{~mL}$ of 15\% EDTA caused dentinal erosion.

Among the essential factors that affect the cleaning properties of EDTA solutions on root canal walls, the $\mathrm{pH}$ of the solution plays a major role. The pH affects $\mathrm{Ca}^{2+}$ availability in several ways. High-pH EDTA solutions induce more chelating activity due to the higher ratio of ionized to nonionized molecules. At high pH values, excess hydroxyl groups will slow down the separation of hydroxyapatite, thus limiting the amount of available $\mathrm{Ca}^{2+}$. At low or neutral $\mathrm{pH}$ levels, the binding effect of $\mathrm{Ca}^{2+}$ will tend to increase the separation of hydroxyapatite and its availability for chelation (30).

MTAD solution developed by Torabinejad et al. (19) is a widely used chelating agent. During the removal of smear layers in root canals, even on long application time of MTAD has been reported to show no significant change in dentin structure (22). Torabinejad et al. (8) reported that the use of MTAD with $5.25 \% \mathrm{NaOCl}$ during the final irrigation of root canals effectively removed the smear layer without changing dentin structure. In our study, we determined that MTAD (20-min application) effectively removed the smear layer in root canal dentin tissue without significantly eroding the perior intratubular areas of the dentinal orifice.

In our study, rotary nickel-titanium file systems and the passive step-back technique were applied to prepare the root canals. Although root canals can be effectively prepared with rotary files, this technique creates a significant amount of smear layer (31). The apical portion of each root canal was prepared to size 30 to allow adequate cleaning and penetration of the solution. Our results demonstrated that MTAD was less destructive to the root canal dentin structure than EDTA when used as a final irrigant. Close examination of the appearance of the root dentinal tubules showed greater amounts of erosion with the EDTA solution (Fig. 1). These findings support the results of recent research, which has reported a correlation between the erosive properties of EDTA and the length of dentin exposure to this material $(8,16,26)$.

Within the limitations of this study, our results suggest that $20 \mathrm{~min}$. application of MTAD during final irrigation caused no significant change in the structure of dentin tubules. In contrast, EDTA solution produced demineralized areas in the dentinal tubules.

\section{Acknowledgments}

The authors deny any conflicts of interest related to this study.

\section{References}

1. Mccomb D, Smith DC. A preliminary scanning electron microscopic study of root canal after endodontic procedures. J Endod 1975;1:238-42.

2. Dautel-morazin A, Vulcain JM, Bonnaure-mallet M. An ultrastructural study of the smear layer: comparative aspects using secondary electron image and backscattered electron image. J Endod 1994;20:531-4.

3. Torabinejad $M$, Handysides $R$, Khademi $A A$, Bakland LK. Clinical implications of the smear layer in endodontics: a review. Oral Surg Oral Med Oral Pathol Oral Radiol Endod 2002;94:65866.

4. Hülsmann $M$, Heckendorff $M$, Lennon $A^{\prime}$. Chelating agents in root canal treatment: mode of action and indications for their use-a review. Int Endod J 2003;36:810-30.

5. Zehnder M. Root canal irrigants. J Endod 2006;32:389-98.

6. Yamada R, Aramas A, Goldman M, Lin PS. A scanning electron microscope comparison of a high volume final flush with several irrigating solutions. Part 3. J Endod 1983;9:137-42.

7. Baumgartner JC, Mader CL. A scanning electron microscopic evaluation of four root canal irrigation regimens. J Endod 1987; 13:147-57.

8. Torabinejad M, Khademi AA, Babagoli J, et al. A new solution for the removal of the smear layer. Journal of Endod 2003;29:170-5.

9. Cruz-Filho AM, Sousa-Neto MD, Saquy PC, Pécora JD. Evaluation of the effect of EDTAC, CDTA, and EGTA on radicular dentin microhardness. J Endod 2001;27:183-4.

10. Estrela C, Holland R, Bernabe' PFE, Souza V, Estrela CRA. Antimicrobial potential of medicaments used in healing process in dog's teeth with apical periodontitis. Braz Dent J 2004;15:181-5.

11. Estrela C, Lopes HP, Elias CN, Leles CR, Pécora JD. Limpeza da superfície do canal radicular pelo vinagre de maçã , hipoclorito de sódio, clorexidina e EDTA. Rev Ass Paul Cir Dent 2007;61:117-22.

12. Hill PK. Endodontics. J Prost Dent 1959;9:142.

13. Loel A. Use of acid cleanser in endodontic therapy. J Am Dent Assoc 1975;90:145-51. 
14. Machado-Silveiro IF, González-López S, GonzálezRodríguez MP. Decalcification of root canal dentine by citric acid, EDTA and sodiumcitrate. Int Endod J 2004;37:365-9.

15. Goldman M, Goldman LB, Cavaleri R, Bogis J, Lin PS. The efficacy of several irrigating solutions for endodontics: a scanning electron microscopic study. Part 2. J Endod 1982;8:487-92.

16. Calt S, Serper A. Time-dependent effects of EDTA on dentin structures. J Endod 2002;28:17-9.

17. Cury JA, Bragotto C, Valdrighi L. The demineralizing efficiency of EDTA solutions on dentin. Part I: influence of $\mathrm{pH}$. Oral Surg Oral Med Oral Pathol Oral Radiol Endod 1981;52:4468.

18. Perez VC, Cardenas MEM, Planells US. The possible role of $\mathrm{pH}$ changes during EDTA demineralization of teeth. Oral Surg Oral Med Oral Pathol Oral Radiol Endod 1989;68:220-2.

19. Torabinejad M, Cho Y, Khademi AA, Bakland LK, Shabahang $S$. The effect of various concentrations of sodium hypochlorite on the ability of BioPure MTAD to remove the smear layer. J Endod 2003;29:233-9.

20. Beltz RE, Torabinejad $M$, Pouresmail $M$. Quantitative analysis of the solubilizing action of MTAD, sodium hypochlorite, and EDTA on bovine pulp and dentin. J Endod 2003;29:334-7.

21. Torabinejad M, Shabahang S, Aprecio RM, Kettering JD. The antimicrobial effect of MTAD: An in vitro investigation. J Endod 2003;29:400-3.

22. Zhang W, Torabinejad M, Li Y. Evaluation of cytotoxicity of MTAD using the MTT-tetrazolium method. J Endod 2003;29:654-7.

23. Berutti $E$, Marini $R$, Angeretti A. Penetration ability of different irrigants into dentinal tubules. J Endod 1997;23:725-7.

24. Haapasalo $M$, Orstavik D. In vitro infection and disinfection of dentinal tubules. J Dent Res 1987;66:1375-9.

25. Mozayeni MA, Javaheri GH, Poorroosta P, Ashari MA, Javaheri HH. Effect of $17 \%$ EDTA and MTAD on intracanal smear layer removal: A scanning electron microscopic study. Aust Endod J 2009;35:13-7.

26. $\mathrm{Hu} X$, Ling J, Gao $Y$. Effects of Irrigation Solutions on Dentin Wettability and Roughness. J Endod 2010;36:1064-7.

27. Grigoratos D, Knowles J, Ng YL, Gulabivala K. Effect of exposing dentine to sodium hypochlorite and calcium hydroxide on its flexural strength and elastic modulus. Int Endod J 2001;34:113-9.

28. Yasuda G, Inage $H$, Kawamoto $R$, et al. Changes in elastic modulus of adhesive and adhesiveinfiltrated dentin during storage in water. J Oral Sci 2008;50:481-6.

29. Niu W, Yoshioka T, Suda H. A scanning electron microscope study of dentinal erosion by final irrigation with EDTA and $\mathrm{NaOCl}$ solutions. Int Endod J 2002;35:934-9.

30. O'connell MS, Morgan LA, Beeler WJ, Baumgartner JC. A comparative study of smear layer removal using different salts of EDTA. ] Endod 2000;26:739-43.
31. Heard F, Walton RE. Scanning electron microscope study comparing four root canal preparation techniques in small curved canals. Int Endod J 1997;30:323-1. 